\title{
Thyroid Gland Hurthle (Oncocytic) Cell Neoplasm
}

National Cancer Institute

\section{Source}

National Cancer Institute. Thyroid Gland Hurthle (Oncocytic) Cell Neoplasm. NCI

Thesaurus. Code C46068.

An adenoma or carcinoma arising from the follicular cells of the thyroid gland. It is composed of large oncocytic cells with abundant granular eosinophilic cytoplasm. 